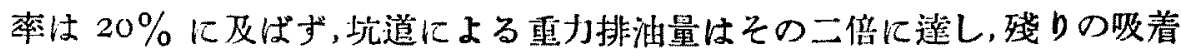
油を㴘水又はアルカリ洗淨法に上つて處理する場合, その牛量を回收し得 る程废であると云ふ。勿論これは比重の大なる粘科な原油の場合である。

\title{
最近本邦に於で發見せられた稀有の晶相及び 結晶面を有する磁鐵鑛に就て
}

Magnetite crystals with unusual crystal habits and faces, re:ently found in Japan

理學博士 原 由 染 平 (Z. Harada)

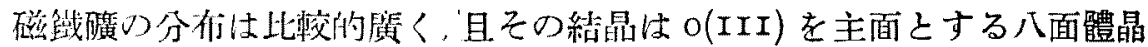

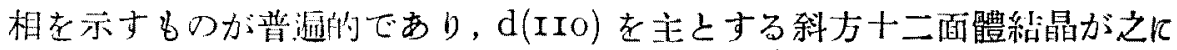
次いでるる。 $\mathrm{a}(\mathrm{IOO})$ を主面とする昆相のものは，其在出が稀であり，殊に $\mathrm{a}(I 00)$ のよりなる立方體絬晶は極めて稀有のものである。この稀有の立

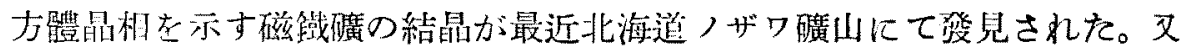
$\mathrm{a}(\mathrm{I} O 0)$ に次いで $\mathrm{n}(2 \mathrm{II})$ 及び $\mathrm{m}(3 \mathrm{II})$ はその存在が比较的稀である。從來 本护に於て $\mathrm{a}(2 \mathrm{II})$ 及び $\mathrm{m}(3 \mathrm{II})$ 有する磁鐵磺の結晶は僅か數個所に童 するに過ざなん。然るにての n(2II) 及び $\mathrm{m}(3 \mathrm{II})$ を有する結昆が宮崎縣 岩戸銓川に詹することな゙非明した。

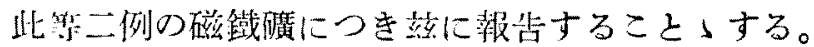

I. 北旅道空知郡山部村ノザワ磺山產磁鐵鑛

ノザワ磺山は北海透空知郡山部村策澤に在り，省線根室本線山部驛の北 東方䄪 2 籸の所に位する。新興磺物である不綿を稼行中の本邦隨一の磺山

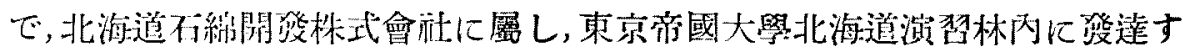
る蛇紋岩中の溫石䋨 (chrysotile) を探取しつ」ある。この石綿磺床に關し ては既に北海道符大鈴木呚授

1）鈴木醇：本橦第 26 枩 (昭和 16 年) $214 \sim 216$. 


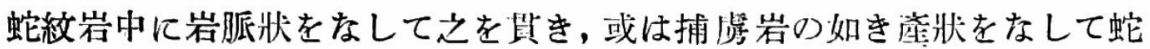
紋岩中に包有せらる」所謂口ヂン苻 (rodingite) は從來北淤近行地は勿論 其他の地方に於ても蛇紋岩中に潑見されてるる1)。

ノザワ礦山の榮澤の露天掘にて稼行中の蛇紋岩中に今回所謂ロヂン岩の

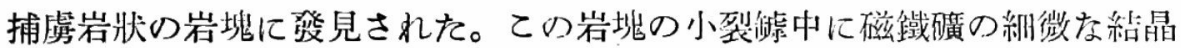

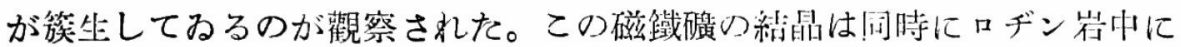
も散點してるる。

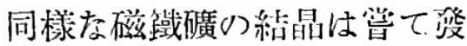
見された间であるが，注意を惹 くに至らなかつたのである。 その磁瀻磺の結品它觀察するに $\mathrm{a}(\mathrm{I} O 0)$ のみよりなる立方體晶相 を示してるる(第壹圖)。結晶は I 粍以下で, a 面は多少等曲曲し， 時にモザィツク構造を示すが， 概して平滑で光澤が强く, 鐵墨 色を是する。結晶の殆んど全部 は a(IOO)のみよりなる單晶で あるが,稀に O(III)の 細微面が 立方體結晶の隅を缺くもの〉傜

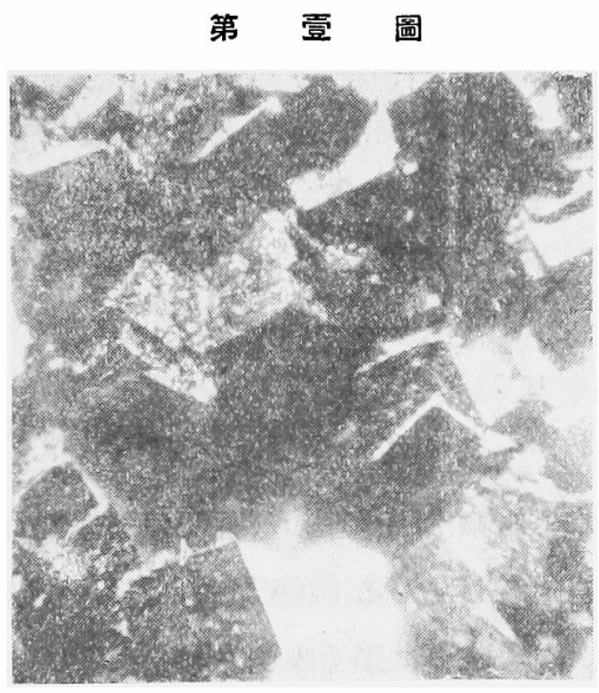

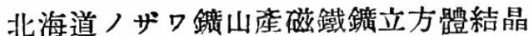
するのも認められる(第式圖)。久立方體結晶の莒入双晶をなすものも存す る。

$\mathrm{a}(\mathrm{IOO})$ のみよりなる單晶は，從來極めて稀有なることは各磺物學孪科畫 及び其他の書物に記誡されてねる2)。a(IOO)のみよりなる立方體晶相を示

1) 鈴木醇: 本誌第 23 卷 (昭和 15 年) 132-135.

2) P.Ramdohr : Klockmann's Lehrbuch der Mineralogie, 11 Aufl.(1936) 401. W. E. Ford: Dana's Textbook of Mineralogy, 4 ed. (1932) 490.

C. Hintze: Handbuoh der Mineralogie. I. 4 Abt. I. Häft. (1933) 34.

E. S. Dana: A System of Mineralogy, 6 ed. 224. 
す絬晶は次の三湖所より䇠するてとが報告されてるるに過ざない。

㺈逸 Obersteiermark 地方の Kraubath 附近の Gulsen.

瑞 典 Nordmark 地方の Mossgrufva

北米 New York 州の Grafschaft Orange $の O^{\prime}$ Niel 坑

此の如き比界的に稀有の晶相を示す磁鐵碩が，今回我國に發見された事 は橴箠すべきことである。

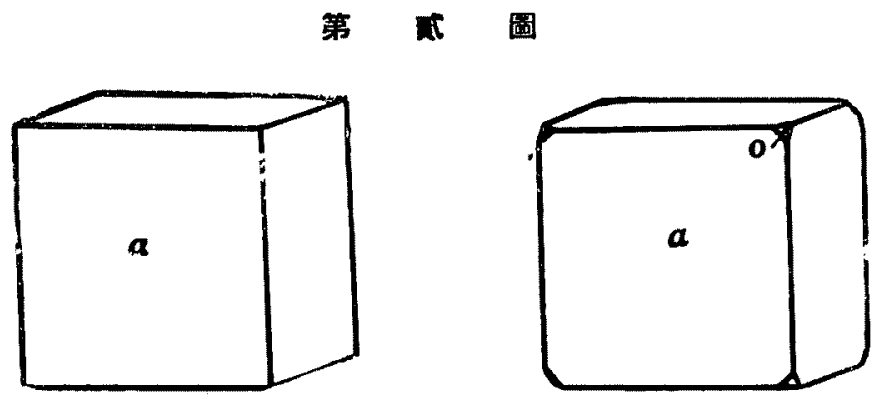

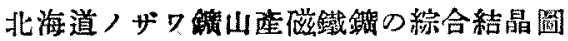

本磁践磺は磁性極めて强く，その表面には探取した時生じた微細な碃物 粉在附着してるる(第壹圖參照)。又之を取外す時には，針の尖端に附着す る。更に磁石に强く吸引される。晸酸にも溶解する。

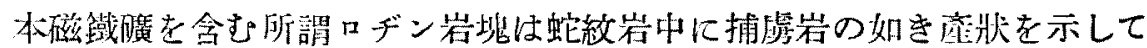
るることは上記の如くである。本口ヂン岩の薄片を鏡下に檢するに主とし

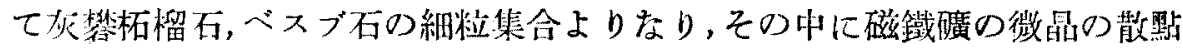
するを見る。

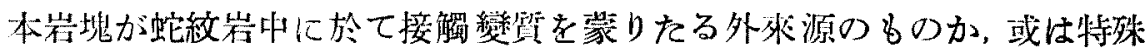

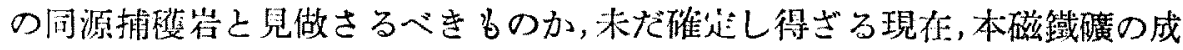
因圭㨁ちに断ずることは出夾ない。

Gulsen に度する立方體磁鐵螾は，本產地と名んど同じく蛇紋岩中に産

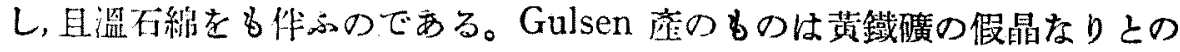


說さへ唱へられてるる11。Gulsen にはての立方體磁鐵磺と共に黃鐵礦童 するが本產地に於ては未だ黃鐵磺の存在は認められてるないし，又直接蛇 岩中に存在するすのでなく，同岩中に包有せらる」ロヂン岩中に得する 點に於て大いに異る。

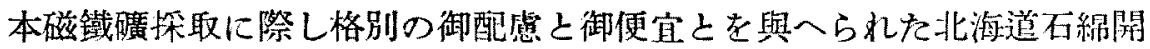

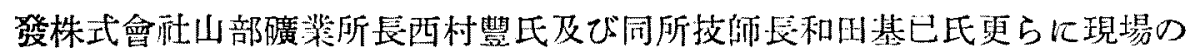
各位に對し滿腔の謝意を表する。又北大鈴木，渡邀雨敎授の御敎示を厚く 感謝する。

\section{2. 宮崎睬西白杵郡岩戶村岩戶銅山崖磁鐵磺}

岩戶銅山は，宮崎瞅西臼杵郡岩戶忖小河內にあり，見立磺山心南々西䄪六

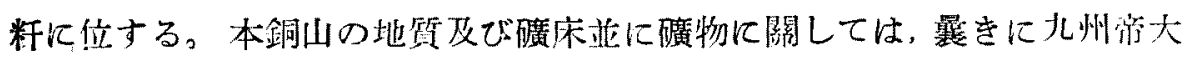
松下助教授 ${ }^{2\}}$ が報告せられ，牧千代太朗學士はまを此地域を調查研究され $\hbar^{3 !}$ 。

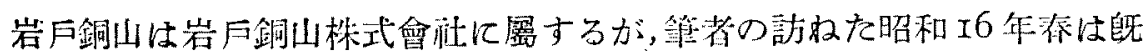
に休山をなしてわた。

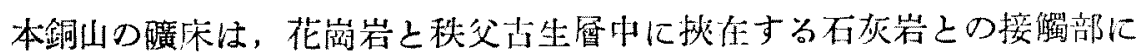

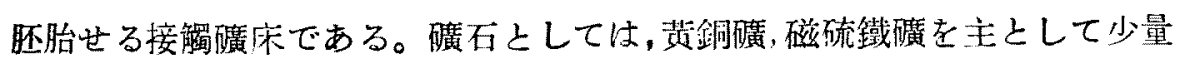
の閃亞鉛矌を混へてるる。脈石としては,方解石, 柘榴石,ベスブ石,へデン

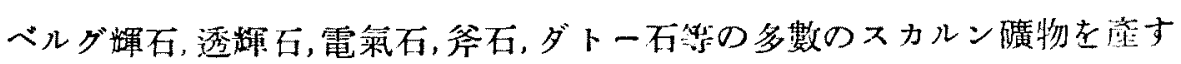
る。茲に述へえとする磁鐵矌は、ベスブ石，釜石，柘榴石等いスカルン磺物

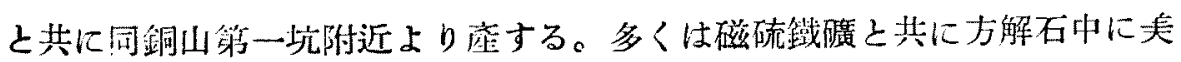
晶をなし、怕狀をなして㷋見される。

絬晶の大きさは直徑 0.2 柾のものより最大 4.5 糎にも蓬し, 就中 1 I I. 5

1) F. Angel u. O. Friedlich: Sitzb. Akad. Wiss. Wien, Abt. I. 144 (1935) $131-143$.

H. Meixner u. L. Walter: Fortsch. Min. Krist. Petro. 23 (1939) 88.

2) 松下久道: 本誌，第 23 卷 (昭和 15 年) 11-123.

3)牧千代太朗：北大卒論(昭和 17 年) 


\section{粝のものが最も多く發見される。}

結晶は主として d(IIO) よりなるが，次の三つの晶相を呈するものが認 められた，

第一型 $\mathrm{d}($ I I O ) の單體

$\mathrm{d}(I I 0)$ のみよりなるものは小なる結晶に多い。稀に O(III) の小面を 有することがある。

第-D型 $\mathrm{d}($ IIO) o(III) 及び $\mathrm{m}(3 \mathrm{II})$ の聚形

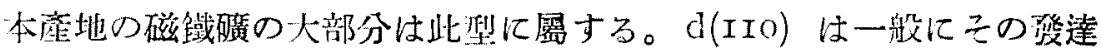
最も良く览に現仙する。m(3II) は大なるてと小なることあり，その 没扂の程度は不規则である。O(III) は常に小面として存するが,稀に

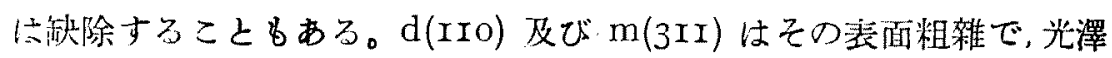
が鈍いのに龂し O(III) は算に强くいてるる。 本晶相を是する一結晶を圖示す れば籍參圖である。

第三啠 $\mathrm{d}(\mathrm{IIO})$ 及び $\mathrm{n}(2 \mathrm{II})$ の聚 形

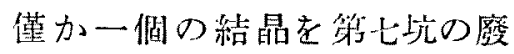
不の中から得たのみである。

$\mathrm{d}(\mathrm{IIO})$ は筑澾著しく, n(2II)は 狹く表はれてるる。

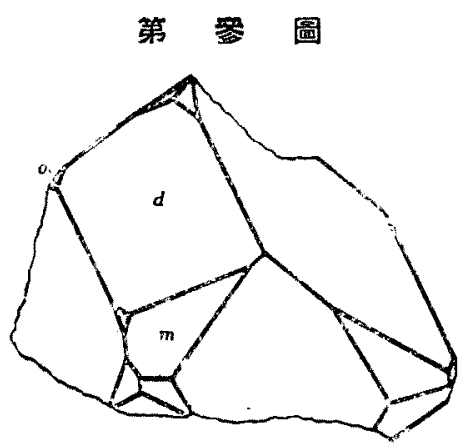

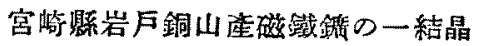

此算三つの晶相の中第二型及び第三型の結晶の綜合結晶圖は第四圖に示 す如くである。

磁鐵礦の結晶は，我國に於てその黄出が、多いにも拘はらず $\mathrm{m}(3 \mathrm{II})$ 及び n (2II) 有するものは，嚾かに次の數個所に於て發見されてわるのに過 ぎない。

$\mathrm{m}(3 I I)$ を有する結晶の產地 
福岡縣田川郡採銅所村三八獕字床屋 ${ }^{1)}$

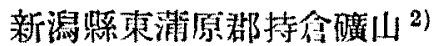

朝鮮江原道三陟郡北三面三和里 ${ }^{3)}$

$\mathrm{n}(2 \mathrm{II})$ 在有す己結昆の应地

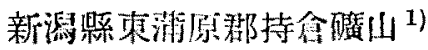

第四圖
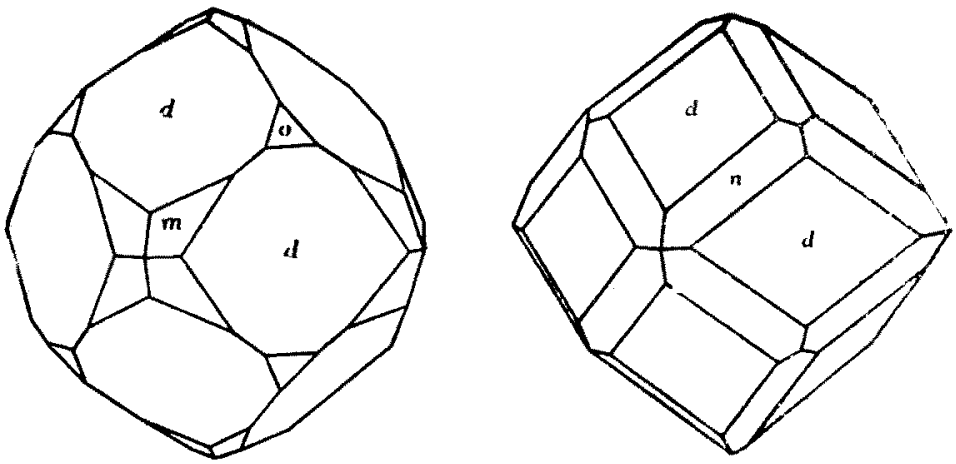

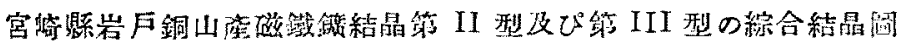

此等の產地及び今回の率地につんて見るに何れる此等 n(2II) 及び（3II） の面を有すろ結晶は接觸礦床に﨎する。

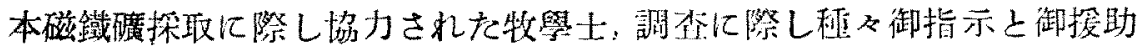

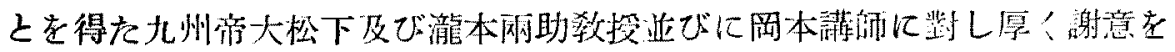
表する。

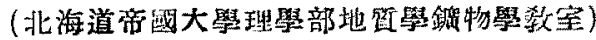

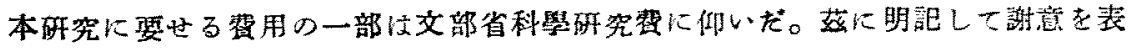
する。

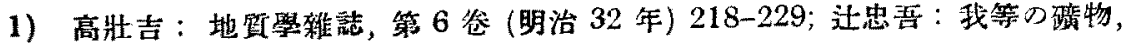
第 8 兊 (昭和 13 年) 190 .

2) 日本鏡物誌 (大正 5 年) 128.

3) 朝鮮箐物誌（大正 11 年） 40 . 